\title{
Role of Renin-Angiotensin System in the Controls of Blood Pressure and Aldosterone in Patients with Cirrhosis and Ascites
}

\author{
Ikuo SaIto, M.D., Takao Saruta, M.D., \\ Toyohisa Eguchi, M.D., Ryuichi Nakamura, M.D., \\ Kazuoki Kondo, M.D., Shigeru Irori, M.D., \\ and Ëichi Kato, M.D.
}

\section{SUMMARY}

In an attempt to evaluate the role of renin-angiotensin system in the controls of blood pressure and aldosterone secretion in the patients with cirrhosis and asictes, 7 patients were infused of an antagonist of angiotensin II, Sar-1 Ile-8 angiotensin II, intravenously to inhibit the action of renin-angiotensin system and to observe changes in arterial pressure and plasma aldosterone. In 1 patient with recent onset of severe ascites and high plasma renin activity, blood pressure and plasma aldosterone decreased during the infusion. In contrast, mild rise in blood pressure and various changes in plasma aldosterone were observed in the other 6 patients with normal plasma renin activity.

These results suggest variable angiotensin dependency in the controls of blood pressure and plasma aldosterone in the patients with cirrhosis and ascites according to the stage of the disease, the states of sodium and water balance and/or plasma renin activity.

\section{Additional Indexing Words :}

Angiotensin II Angiotensin II analogue Plasma renin activity

Liver disease Edema Secondary aldosteronism

T $\mathrm{N}$ an experimental model of hyperaldosteronism secondary to increased - plasma renin activity such as chronic sodium depletion or thoracic inferior vena caval constriction, it is well recognized that angiotensin II is critically involved in the maintenances of arterial pressure and aldosterone secretion. ${ }^{1)}$ Clinically, it is suggested that renin-angiotensin system is activated secondarily to decreased effective plasma volume ${ }^{2-5)}$ and plays an important role in salt and water retention in the patients with liver cirrhosis and ascites, ${ }^{6}$ ) however, the role of renin-angiotensin system in the maintenance of arterial pressure has not been clearly defined in thesc patients.

From the Department of Internal Medicine, Keio University School of Medicine, 35 Shinanomachi, Shinjuku-ku, Tokyo 160, Japan.

Received for publication March 8, 1978. 
The recent availability of an inhibitor of renin-angiotensin system has provided means for more precise analysis of this problem. ${ }^{7), 81}$ The present study was undertaken to elucidate whether the controls of blood pressure and plasma aldosterone in the patients with cirrhosis and ascites are angiotensin-dependent by means of a specific antagonist of angiotensin II (Sar-1 Ile-8 angiotensin II).

\section{Subjects and Methods}

Seven patients having cirrhosis with ascites were studied as inpatients in the Keio University Hospital. Each had physical and laboratory evidences of cirrhosis, confirmed by biopsy in 3 cases. Clinical and biochemical characteristics in these subjects are presented in Tables I and II. Medication was withdrawn at least 2 weeks before the examination. All subjects were placed on the diet containing $140-180 \mathrm{mEq}$ of sodium and $80-100 \mathrm{mEq}$ of potassium per day. All stuides

Table I. Baseline Assessment of Blood Chemistry in the Patients

\begin{tabular}{l|c|c|c|c|c|c|c|c}
\hline Patient & $\begin{array}{c}\text { Age \& } \\
\text { Sex }\end{array}$ & $\begin{array}{c}\text { Total protein } \\
(\mathrm{Gm} / 100 \mathrm{ml})\end{array}$ & $\begin{array}{c}\text { A/G } \\
\text { ratio }\end{array}$ & $\begin{array}{c}\text { GOT } \\
(\mathrm{U})\end{array}$ & $\begin{array}{c}\mathrm{GPT} \\
(\mathrm{U})\end{array}$ & $\begin{array}{c}\mathrm{Na} \\
(\mathrm{mEq} / \mathrm{L})\end{array}$ & $\begin{array}{c}\mathrm{K} \\
(\mathrm{mEq} / \mathrm{L})\end{array}$ & $\begin{array}{c}\mathrm{Cr} \\
(\mathrm{mg} / 100 \mathrm{ml})\end{array}$ \\
\hline K. E. & $58 \mathrm{M}$ & 6.9 & 0.6 & 127 & 74 & 138 & 4.2 & 1.0 \\
S. S. & $65 \mathrm{M}$ & 6.7 & 1.0 & 69 & 85 & 142 & 3.5 & 1.1 \\
T. F. & $46 \mathrm{M}$ & 6.2 & 1.0 & 89 & 53 & 141 & 3.7 & 1.2 \\
S. H. & $68 \mathrm{~F}$ & 5.2 & 1.1 & 55 & 25 & 140 & 2.5 & 1.1 \\
T. Y. & $42 \mathrm{M}$ & 5.8 & 0.7 & 95 & 17 & 138 & 2.6 & 2.1 \\
H. A. & $50 \mathrm{~F}$ & 5.6 & 1.0 & 15 & 34 & 139 & 2.8 & 1.2 \\
M. K. & $60 \mathrm{~F}$ & 7.6 & 0.8 & 143 & 65 & 140 & 3.0 & 1.1
\end{tabular}

$\mathrm{A} / \mathrm{G}=$ Albumin/Globulin, GOT $=$ Glutamic oxaloacetic transaminase, GPT =Glutamic pyruvic transaminase, $\mathrm{Cr}=$ Serum creatinine

Table II. Responses of Blood Pressure and Plasma Aldosterone in Patients with Cirrhosis and Ascites

\begin{tabular}{l|c|cc|rc}
\hline \multirow{2}{*}{ Patient } & \multirow{2}{*}{$\begin{array}{c}\text { Control } \\
\text { PRA } \\
\text { (ng/ml/hr) }\end{array}$} & \multicolumn{2}{|c|}{$\begin{array}{c}\text { Blood Pressure } \\
(\mathrm{mmHg})\end{array}$} & \multicolumn{2}{c}{$\begin{array}{c}\text { Plasma Aldosterone } \\
\text { (ng/100 ml) }\end{array}$} \\
\cline { 3 - 6 } & 2.6 & $122 / 80$ & $98 / 68$ & 15.0 & Control \\
\cline { 3 - 5 } K. E. & 0.9 & $128 / 72$ & $150 / 80$ & 0.5 & 2.0 \\
S. S. & 1.2 & $156 / 92$ & $178 / 106$ & 11.2 & 11.0 \\
T. F. & 1.6 & $118 / 60$ & $142 / 78$ & 6.2 & 3.0 \\
S. H. & 1.4 & $134 / 88$ & $140 / 90$ & 13.4 & 17.6 \\
T. Y. & 1.6 & $100 / 60$ & $132 / 80$ & 10.0 & 13.0 \\
H. A. & 1.8 & $180 / 90$ & $220 / 100$ & 8.0 & 7.0 \\
M. K. & & & & & Infusion \\
\end{tabular}

$\mathrm{PRA}=$ Plasma renin activity 
were performed in the morning after an overnight fast with the patients having been supine for 10 hours. Graded infusion of Sar-1 Ile-8 angiotensin II (100, 300, $600 \mathrm{ng} / \mathrm{Kg} / \mathrm{min}$ at intervals of $10 \mathrm{~min}$ was performed after a control period of at least $30 \mathrm{~min}$. Blood pressure was measured with sphygnomanometer by a physician every $3 \mathrm{~min}$ during the control period and during the infusion. Blood samples for determinations of plasma renin activity and aldosterone were drawn before and after the infusion of the antagonist.

Informed consent was obtained from each patient.

Plasma aldosterone was determined by radioimmunoassay. ${ }^{91}$ Plasma renin activity was measured by the method of Skinner (1968). ${ }^{10)}$ Normal values in our laboratory are $7.0 \pm 5.0 \mathrm{ng} / 100 \mathrm{ml}$ for aldosterone and $1.7 \pm 0.5 \mathrm{ng} / \mathrm{ml} / \mathrm{hr}$ for renin activity.

\section{RESULTS}

The maximum increase or decrease in blood pressure was observed at a infusion rate of $600 \mathrm{ng} / \mathrm{Kg} / \mathrm{min}$. Changes in blood pressure and plasma aldostcrone are shown in Table II. Baselinc plasma renin activity was within normal ranges in 6 patients with pressor response, while it was high in one patient with depressor response. The patient with depressor response (K. E.) had recent clinical onset of severe ascites and edema and showed decrease in plasma aldosterone in response to angiotensin II analogue. In the other patients, slight increase or no change in plasma aldosterone was observed in response to Sar-I Ile-8 angiotensin II.

\section{Discussion}

The present study demonstrated that the infusion of Sar-I Ile-8 angiotensin II induced depressor response in 1 of 7 patients with cirrhosis and ascites. Yamamoto et al $^{11}$ have also reported that blood pressure declined by the same angiotensin II analogue in 1 out of 3 patients with cirrhosis and ascites, By the infusion of another angiotensin II analogue (Sar-1 Ala-8 angiotensin II), Schroeder et al ${ }^{12}$ revealed decrease in blood pressure in 5 out of 7 patients with cirrhosis and ascites and suggested that the control of arterial pressure in these patients was angiotensin-dependent. Observation by Johnson et al $^{1)}$ has demonstrated that the infusion of Sar-1 Ala-8 angiotensin II decreased the blood pressure of dogs with thoracic caval constriction, which were similar to the patients with cirrhosis and ascites hemodynamically. ${ }^{13), 14 \text { ) }}$

It is worthy to note that most of the patients with cirrhosis and ascites showed pressor response in the studies of Yamamoto et al11) and ours compared with the high incidence of depressor response in the study of Schroeder 
et al. ${ }^{12)}$ There are several possible explanations for the discrepancy in the incidence of depressor response. One is the difference in the forms of the inhibitor of angiotensin II. Sar-1 Ile-8 angiotensin II, a potent competitive antagonist of angiotensin II in vitro ${ }^{151,16)}$ was employed in our study. It is recognized that this analogue shows depressor effect on patients with renovascular or malignant hypertension with high plasma renin activity ${ }^{17)}$ and complete blockade of the pressor effect of exogenously infused $1600 \mathrm{ng} / \mathrm{Kg}$ of angiotensin II at a rate of $1000 \mathrm{ng} / \mathrm{Kg} / \mathrm{min}$ in rabbits. ${ }^{18)}$ However, it induces pressor response in patients with low or normal renin activity because of its partial agonist activity, that has already been observed in the use of Sar-1 Ala-8 angiotensin II. ${ }^{19), 20)}$

Another possibility is the difference in the sodium intake by the patients. The patients in the present study were on normal sodium diet and therefore most of them showed normal or slightly decreased plasma renin activity while the patients of Schroeder et al on the diet containing $10 \mathrm{mEq}$ of sodium had maximally activated plasma renin activity. Since the response to the angiotension II inhibitor is fairly dependent on the states of sodium and water balance and/or plasma renin activity, prior sodium restriction induces the elevation of plasma renin activity and the increase in the incidence of depressor response..$^{21-25)}$ Thus, the response to the angiotensin II analogue during sodium depletion is an influence of sodium depletion per se rather than a measure of intrinsic angiotensin II dependency of the disease.

The third possibility is the difference in the state of compensation in the process of the disease per se. Watkins et al $(1976)^{26)}$ revealed that reninangiotensin system played an important role in the maintenance of blood pressure during the initial stage, but not during the later stage of thoracic caval constriction in dogs since the administration of a converting enzyme inhibitor, which blocked the conversion of angiotensin I to angiotensin $\mathrm{II}^{27}$, reduced blood pressure during the initial stage but not in the later stage. In the present study, plasma renin activity of the patient who had depressor response (K.E.) was elevated in spite of normal sodium intake. Because of his recent development of severe ascites, it was assumed that the hemodynamic compensation to decreased effective plasma volume was limited and inadequate and thus plasma renin activity remained elevated when the study was performed. Other patients with pressor response, having longer history of cirrhosis and ascites and showing normal or low plasma renin activity, were supposed to bc in the statc of compensation. From these results, it is suggested that the difference in the hemodynamic compensation is an important factor to determine the intrinsic angiotensin II dependency in the maintenance of blood pressure in the patients with cirrhosis and ascites. 
In the present study, we were unable to demonstrate the angiotensindependency of steroidogenesis in the adrenal glands in most of the patients with cirrhosis and ascites in contrast to the study by Schroeder et al. Four humoral changes have been shown to participate in the control of aldosterone. 28)-32) They are increased concentrations of angiotensin II, adrenocorticotropic hormone (ACTH), and serum potassium, and reduced level of serum sodium. Among these factors, when renin-angiotensin system is activated by prior sodium depletion to regulate aldosterone secretion exclusively, plasma aldosterone will decline in response to the infusion of an angiotensin II analogue. Since the renin-angiotensin system was not activated by prior sodium restriction in the present study, it is supposed that not only renin-angiotensin system but also other factors were involved in the control of aldosterone secretion and various changes in plasma aldosterone were observed after the infusion of Sar-1 Ile-8 angiotensin II. Further, the duration of infusion of the angiotensin II inhibitor was too short to make clear the intrinsic angiotensindependency of aldosterone secretion by the adrenal gland, ${ }^{33)}$ particularly in the patient with liver cirrhosis associated with a prolonged half-life of aldosterone. $^{34)}$

In summary, the role of renin-angiotensin system for the maintenances of arterial pressure and aldosterone secretion in the patients with cirrhosis and ascites is variable according to the state of sodium and water balance and/or the stage of the disease per se.

\section{REFERENCES}

1. Johnson JA, Davis JO: Effects of a specific competitive antagonist of angiotensin II on arterial pressure and adrenal steroid secretion in dogs. Circulat Res 32 (suppl 1): 159, 1973

2. Laragh $\mathbf{J H}$, Cannon PJ, Ames RP: Interaction between aldosterone secretion, sodium and potassium balance and angiotensin activity in man; studies in hypertension and cirrhosis. Canad Med Ass J 90: 248, 1964

3. Ayers CR: Plasma renin activity and renin substrate concentration in patients with liver disease. Circulat Res 20: 594, 1967

4. Schroeder ET, Eich RH, Smulyan H, Gould AB, Gabuzda GJ: Plasma renin level in hepatic cirrhosis. Relation to functional renal failure. Am J Med 49: 186, 1970

5. Rosoff L, Zia P, Reynolds T, Horton R: Studies of renin and aldosterone in cirrhotic patients with ascites. Gastroenterology 69:698, 1975

6. Kondo K, Nakamura R, Saito I, Saruta T, Matsuki S: Renin, angiotensin II and juxtaglomerular apparatus in liver cirrhosis. Jap Circulat J 38: 913, 1974

7. Brunner HR, Gavras H, Laragh JH, Keenan R: Angiotensin II blockade in man by Sar' ${ }^{-}$ $\mathrm{Ala}^{8}$ angiotensin $\mathrm{II}$ for understanding and treatment of high blood pressure. Lancet II: 1045,1973

8. Davis JO, Freeman RH, Johnson JA, Spielman WS: Agents which block the action of the renin-angiotensin system. Circulat Res 34: 279, 1974

9. Bayard F, Beitius IZ, Kowarski A, Migeon CJ: Measurement of aldosterone secretion rate by radioimmunoassay. J Clin Endocr 31: 507, 1970 
10. Skinner SL: Improved assay methods for renin concentration ard activity in human plasma. Circulat Res 20: 391, 1968

11. Yamamoto $T$, Doi $K$, Ogihara $T$, Kumahara $Y$, Hata $T$ : Clinical application of angiotensin II analogue. Folia Endocrinol Jap 52: 619, 1976

12. Schroeder ET, Anderson GH, Goldman SH, Streeten DHP: Effect of blockade of angiotensin II on blood pressure, renin and aldosterone in cirrhosis. Kid Intern 9 : 511 , 1976

13. McKee FW, Schilling JA, Tishkoff GH, Hyatt RE: Experimental ascites: Effects of sodium chloride and protein intake on protein metabolism of dogs with constricted inferior vena cava. Surg Gyn and Obst 89: 529, 1949

14. Lohmeier TE, Davis JO, Hanson RC, Williams GM: Renin-angiotensin-aldosterone system in rabbits with thoracic caval constriction. Am J Physiol 232: F559, 1977

15. Turker RK, Hall MN, Yamamoto M, Sweet C, Bumpus FM: A new longlasting competitive inhibitor of angiotensin. Science 177: 1203, 1972

16. Saltman S, Fredlund $\mathrm{P}$, Catt $\mathrm{KJ}$ : Action of angiotensin II antagonists upon aldosterone production by isolated adrenal glomerulosa cells. Endocrinology 98: 894, 1976

17. Ogihara T, Yamamoto T, Kumahara Y: Clinical application of synthetic angiotensin II analogue. Jap Circulat J 38: 997, 1974

18. Romero JC, Holmes DR, Strong GG: The effect of high sodium intake and angiotensin antagonist in rabbits with severe and moderate hypertension induced by constriction of one renal artery. Circulat Res $\mathbf{4 0}$ (suppl 1): 17, 1977

19. Streeten DHP, Freiberg JM, Anderson GH, Dalakos TG: Identification of angioterisionogenic hypertension in man using 1-Sar 8-Ala angiotensin II. Circulat Res 36 and $\mathbf{3 7}$ (suppl 1): 125,1975

20. Hollenberg NK, Williams GH, Burger B, Ishikawa I, Adams DF: Blockade and stimulation of renal, adrenal and vascular angiotensin II receptors with 1-Sar 8-Ala angiotensin II in normal man. J Clin Invest 57: 39, 1976

21. Brunner HR, Gavras H, Laragh JH: Hypertension in man. Exposure of the renin and sodium components using angiotensin II blockade. Circulat Res 36 and 37 (suppl 1): 35, 1974

22. Spielman WS, Davis JO: The renin angiotensin system and aldosterone secretion during sodium depletion in the rat. Circulat Res 35: 615, 1974

23. Gavras H, Bieiro AB, Gavras I, Brunner HR: Reciprocal relation between renin dependency and sodium dependency in essential hypertension. N Engl J Med 295: 1278, 1976

24. Case DB, Wallace JM, Keim HJ, Sealey JE, Laragh JH: Usefulness and limitations of salarasin, a partial competitive agonist of angiotensin II, for evaluating the renin and sodium factors in hypertensive patients. Am J Med 60: 825, 1976

25. Peach MJ, Sarsted CA, Vaughan ED: Changes in cardiovascular and adrenal cortical responses to angiotensin III induced by sodium deprivation in the rat. Circulat Res 38 (suppl 2): 117, 1976

26. Watkins L, Burton JA, Haber E, Cant JR, Smith FW, Barger AC: The renin-angiotensinaldosterone system in congestive failure in conscious dogs. J Clin Invest 75: 1606, 1976

27. Bakhle YS: Inhibition of angiotensin I converting enzyme by venom peptide. Brit J Pharmacol 43: 252, 1971

28. Scholer D, Birkhaeuser A, Peytreman A, Riondol AM, Vallotton MB, Muller AF: Response of plasma aldosterone to angiotensin II, ACTH and potassium in man. Acta Endocrinol 72: 293, 1972

29. Saruta T, Cook R, Kaplan NM: Adrenocortical steroidogenesis. Studies on the mechanism of action of angiotensin and electrolytes. J Clin Invest 51 : 2239,1972

30. Williams GH, Cain JP, Dluhy RG, Underwood RH: Studies of the control of plasma aldosterone concentration in normal man. 1. Response to posture, acute and chronic volume depletion and sodium loading. J Clin Invest 51: 1731, 1972

31. Dluhy RG, Himathongkam T, Greenfield M: Rapid ACTH test with plasma aldosterone 
levels. Improved diagnostic discrimination. Ann Intern Med 80: 693, 1974

32. Himathongkam T, Dluhy RG, Williams GH: Potassium-aldosterone-renin interrelationship. J Clin Endocrinol Metab 41: 153, 1975

33. Pettinger WA, Mitchell HC: Clinical pharmacology of angiotensin antagonists. Fed Proc 35: 2521,1976

34. Coppage WS Jr, Island DP, Cooner AE, Liddle GW: The metabolism of aldosterone in normal subjects and in patients with hepatic cirrhosis. J Clin Invest 41:1672, 1962 